\title{
An analysis of geochemical features of crystallization of emeralds as an approach to determine the deposit of them
}

\author{
Mikhail Petrovich POPOV $1,2 *$ \\ Vladimir Ivanovich SOLOMONOV ${ }^{3,4 * *}$ \\ Al'fiya Vilikovna SPIRINA ${ }^{3 * * *}$ \\ Mikhail Alekseevich IVANOV 5 , \\ Victoria Vadimovna KUPTSOVA ${ }^{5}$, \\ Anatoliy Germanovich NIKOLAEV ${ }^{6 * * *}$ \\ ${ }^{1}$ Ural State Mining University, Ekaterinburg, Russia \\ ${ }^{2}$ The Zavaritsky Institute of Geology and Geochemistry of the Ural Branch of RAS, Ekaterinburg, Russia \\ ${ }^{3}$ Institute of Electrophysics of the Ural Branch of RAS, Ekaterinburg, Russia \\ ${ }^{4}$ Ural Federal University named after the First President of Russia B. N. Yeltsin, Ekaterinburg, Russia \\ ${ }^{5}$ Military Unit 68240, Moscow, Russia \\ ${ }^{6}$ Kazan (Volga region) Federal University, Kazan, Russia
}

\begin{abstract}
Relevance. It is known that minerals differ in morphology, features of the internal structure of crystals, chemical composition, etc., depending on the conditions of their formation and existence. These geochemical features of the gems crystallization are an important criterion for determining their deposit. In this paper, the impurity composition of the samples of emeralds from the deposits of Brazil, China, Zambia, Russia, Afghanistan, Colombia, and Tanzania was investigated by X-ray fluorescent analysis. The study of the impurity composition of emeralds by a non-destructive method and the construction of analytical dependences can be used as an additional way for determining the deposit of emeralds.

Purpose of the work is the study of chemical composition of emeralds by X-ray fluorescent analysis to establish the relationship between the content of the main impurity elements and the deposit.

Results. The data on the impurity composition of emeralds obtained by X-ray fluorescent analysis show that the content of impurities of $\mathrm{Na}, \mathrm{K}, \mathrm{Rb}, \mathrm{Cs}, \mathrm{Mg}, \mathrm{Fe}, \mathrm{V}, \mathrm{Cr}$ differs from one deposit to another. The content of impurities of alkali metals and magnesium is higher in the samples from the shale-type deposits compared to the samples from deposits of the Colombian type. Thus, at the first stage, the type of deposit can be assumed. Further, the dependences plotted in the coordinate planes $\{\mathrm{Cr}, \mathrm{V}\},\{\mathrm{Cs}, \mathrm{Cr}\},\{\mathrm{Fe}, \mathrm{Cr}\}$ show separate areas, delimited by the impurity ratios, which are typical for the samples from deposits in China, Colombia, Zambia, Afghanistan, and Tanzania.

Conclusion. X-ray fluorescent analysis, as a non-destructive method for studying emeralds, is considered to be a promising approach to identifying their deposit, but as an additional method.
\end{abstract}

Keywords: emerald, deposit, impurity composition, X-ray fluorescent analysis.

\section{Introduction}

There are two main geological and industrial types of emerald deposits. The first one is represented by carbonate-pyrite-albite-quartz veins in carbonaceous and calcareous schists $[1,2]$. Sometimes they are formed in terrigenous-carbonate and sulfate-terrigenous-carbonate rocks [3]. The main large deposits are located in Colombia, so this region gave its name to one of the type of emeralds. Similar deposits and occurrences of emerald were found in the Panjshir Valley in Afghanistan [4]. Up to $75-80 \%$ of world production comes from deposits of this type. Objects of this type have a hydrothermal nature of formation. Typical inclusions in emeralds of the first type are the following ones: carbonaceous shales, halite and calcite crystals, grains of quartz, pyrite, and feldspar (albite).

Deposits of the second type are mainly confined to sheared bodies of basic and ultrabasic composition or unmetamorphosed ultramafic rocks at intrusive or tectonic contacts with silicate rocks. The most favourable host rocks for emerald mineralization are biotite or phlogopite metasomatic shales [5]; therefore, this type of deposits is called shale-type. The most famous shale-type deposits are: Ural Emerald Mines (Russia), Habachtal (Austria), Karnaiba and Santa Terezinha (Brazil); Kafubu (Zambia), Franqueira (Spain), Kianjavato and Ianapera (Madagascar), Mingora (Pakistan). The host rocks found

\footnotetext{
$\triangle$ popovm1@yandex.ru

http://orcid.org/0000-0002-0527-8234

*plasma@iep.uran.ru

**xasuleva@iep.uran.ru

****anatolij-nikolaev@yandex.ru
} 
in the "suture zones" usually form a "tectonic melange" $[6,7]$. In addition, the host rocks of emerald mineralization are often metamorphosed volcanic rocks of basic composition. These can be epidote-chlorite-actinolite rocks, chlorite and talc-chlorite shales (Kafubu deposit, Zambia) [8], basic gneisses and amphibolites (Tanzania, Madagascar) [9]. Often, ore bodies with emeralds are located near the contacts of pegmatites with apobasic and apohyperbasic micas (Karnaiba deposit, Brazil and Mananjary deposit, Madagascar). In deposits of the second type, emerald is found in mica (rocks consisting of phlogopite).

In forensic research, it is often necessary to determine the extraction site of any given stone material. In this regard, it becomes necessary to develop methods for identifying the genuineness of the extraction site. Each deposit is characterized by special geochemical features of the crystallization of stones, so they must show themselves as signs of belonging to a certain deposit of stones. Earlier some works have shown [10-14] that such features are manifested in the form of a variable composition of impurity ions-chromophores and affect the luminescence spectrum. It fundamentally shows that with a sufficient sample of minerals from different deposits, their measured spectral-luminescent parameters (mean wavelength, dispersion and inverse effective luminescence bandwidth in the range 660-870 nm) obey the laws of mathematical statistics.

Purpose of this work is study of the chemical composition of emeralds by X-ray fluorescent analysis to establish the relationship between the content of the main impurity elements and the deposit, which can be used as an additional method for determining the emerald deposits.

Instruments and samples

Determination of the content of impurity elements $\mathrm{Na}$, $\mathrm{Mg}, \mathrm{K}, \mathrm{Fe}, \mathrm{Rb}, \mathrm{Cs}, \mathrm{V}$ and $\mathrm{Cr}$, was carried out using the method of X-ray fluorescent analysis (RFA) by the EDX-8000 spectrometer according to $K_{\alpha}$ - lines of the indicated elements. The instrument was calibrated by the method of fundamental parameters using reference standards. The RFA spectra were recorded in a vacuum, the voltage and current for the X-ray tube were $30-50 \mathrm{kV}$ and $250-1000 \mu \mathrm{A}$, the collimator for the installed samples had a diameter of $3 \mathrm{~mm}$, the registration time for 1 sample did not exceed $100 \mathrm{sec}-$ onds. In the range of measured contents of $0.01-1.5 \mathrm{wt} . \%$, the percentage error of the device does not exceed $20 \%$ [15]. The research was carried out in the laboratory of the Zavaritsky Institute of Geology and Geochemistry.

Most of the samples of emeralds from major world deposits were purchased at the Russian mineralogical exhibitions "Mineral-Show" (Ekaterinburg) and "Gemma" (Moscow). Some of the material was acquired at international mineralogical fairs in Munich (Germany) and Tusson (USA). Thus, samples were acquired from the major world deposits of Brazil, China, Zambia, Russia, Afghanistan, Colombia, and Tanzania. More than 100 specimens per each deposit were examined.

Since the samples usually had a zonal color, they were cut into pieces of the same color for objective research.

Results of the study and discussion

All the samples were examined on the presence of impurities of alkali metals ( $\mathrm{Na}, \mathrm{K}, \mathrm{Rb}, \mathrm{Cs})$, magnesium, and ions-chromophores as well. The data on their content (in wt.\%) for seven world deposits of emeralds are summarized in table 1 . The values are given in ranges due to the dispersion among a large number of samples for each deposit.

The data in the table show that each deposit is characterized by features manifested in an increased (yellow cell color) or decreased (green cell color) content of any impurity. At that, the content of the same impurity for different deposits can meet the same range.

The content of impurities of some alkali metals and magnesium in emeralds differs depending on the deposit. Their increased content is associated with inclusions of phlogopite, muscovite, and ultrabasic host rocks, which is inherent to the shale-type of the deposit. Thus, already at the first stage of emerald identification, one can assume the type of deposit of this stone.

Further analysis of the obtained data showed that in separate coordinate planes it is possible to select areas inherent to certain deposits. Fig. 1-3 show the relationship between the impurities which is plotted in the planes $\{\mathrm{Cr}, \mathrm{V}\},\{\mathrm{Cs}, \mathrm{Cr}\},\{\mathrm{Fe}, \mathrm{Cr}\}$. In each figure, for greater clarity, the data are separated into groups of fields, where

Table 1. Ranges of values of impurities in emeralds of various deposits, wt. \%

Таблица 1. Диапазоны значений содержаний примесей в изумрудах различных месторождений, масс.\%

\begin{tabular}{|c|c|c|c|c|c|c|c|}
\hline Element & Afghanistan & Zambia & Brazil & China & Russia & Colombia & Tanzania \\
\hline $\mathrm{Na}$ & $0.38-0.72$ & $0.38-1.23$ & $0.45-1.25$ & $0.55-1.55$ & $0.41-1.50$ & $0.43-1.65$ & $0.43-0.85$ \\
\hline $\mathrm{K}$ & $0.612-0.779$ & $0.62-2.45$ & $0.61-1.30$ & $0.61-1.30$ & $0.60-1.93$ & $0.60-1.05$ & $0.61-3.30$ \\
\hline $\mathrm{Rb}$ & $0.0003-0.0036$ & $0.001-0.013$ & $0.0005-0.0055$ & $0.0005-0.0055$ & $0.0002-0.0176$ & $0.0002-0.0043$ & 0.0004-0.0064 \\
\hline Cs & $0.007-0.029$ & $0.012-0.193$ & $0.017-0.137$ & $0.013-0.143$ & $0.0025-0.1429$ & $0.007-0.095$ & $0.008-0.086$ \\
\hline $\mathrm{Mg}$ & $0.266-1.590$ & $0.10-0.86$ & $0.36-2.50$ & $0.36-2.50$ & $0.26-2.39$ & $0.25-0.58$ & $0.33-2.18$ \\
\hline $\mathrm{Fe}$ & $0.597-3.310$ & $0.57-1.81$ & $0.56-2,02$ & $0.55-1.14$ & $0.52-0.98$ & $0.52-0.88$ & $0.60-1.69$ \\
\hline V & $0.004-0.215$ & $0.004-0.699$ & $0.004-0.021$ & $0.07-0.83$ & $0.004-0.042$ & $0.004-0.269$ & $0.004-0.397$ \\
\hline $\mathrm{Cr}$ & $0.06-0.79$ & $0.022-0.535$ & $0.008-0.505$ & $0.012-0.173$ & $0.0036-0.4172$ & $0.011-0.269$ & $0.053-0.885$ \\
\hline
\end{tabular}

Note: maximum values are highlighted in yellow; minimum values are highlighted in green.

Примечание. Желтым цветом выделены максимальные значения, зеленым - минимальные. 


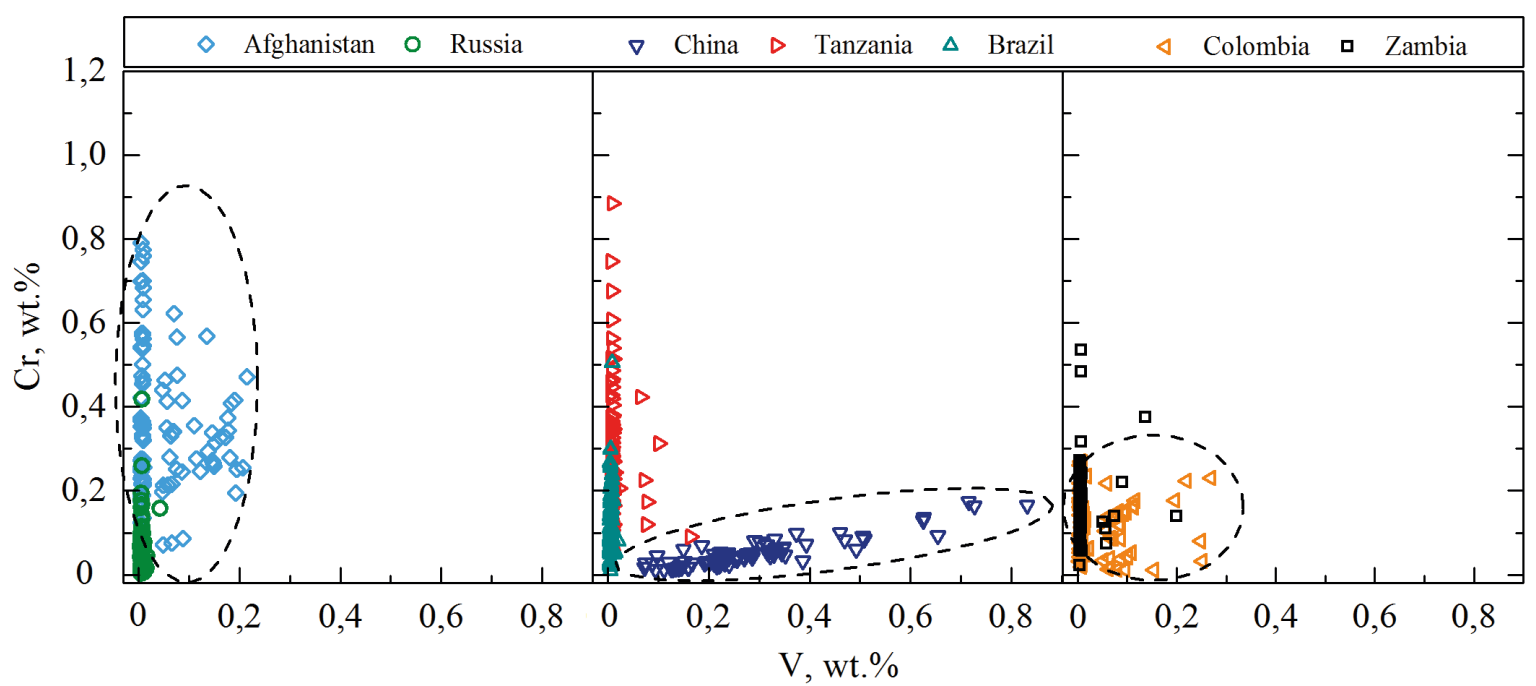

Figure 1. Distribution of emeralds of different deposits in the plane $(\mathrm{Cr}-\mathrm{V})$ Рисунок 1. Распределение изумрудов разных месторождений в плоскости (Cr-V)

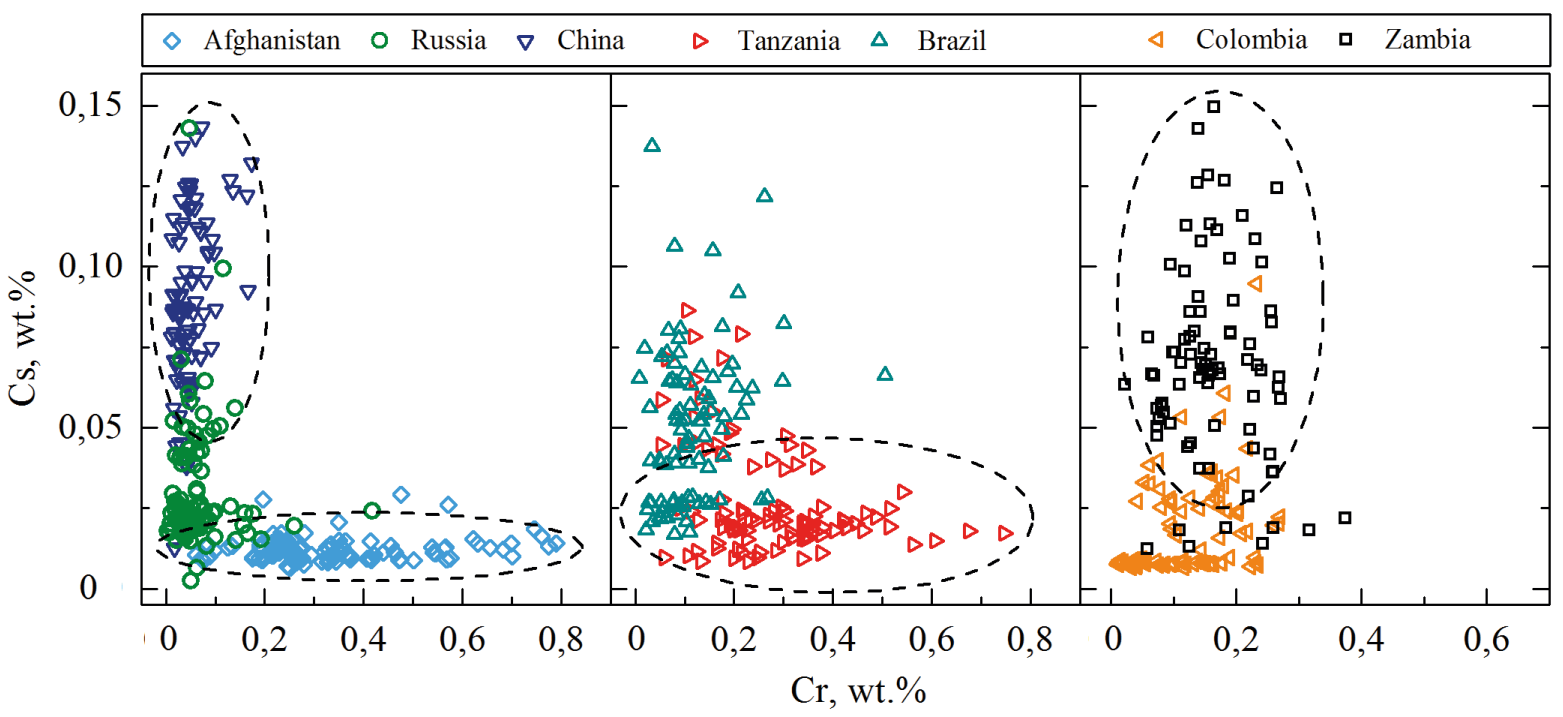

Figure 2. Dependence of the ratio in emeralds of cesium with chromium (Cs-Cr) Рисунок 1. Зависимость соотношения в изумрудах цезия с хромом (Cs-Cr)

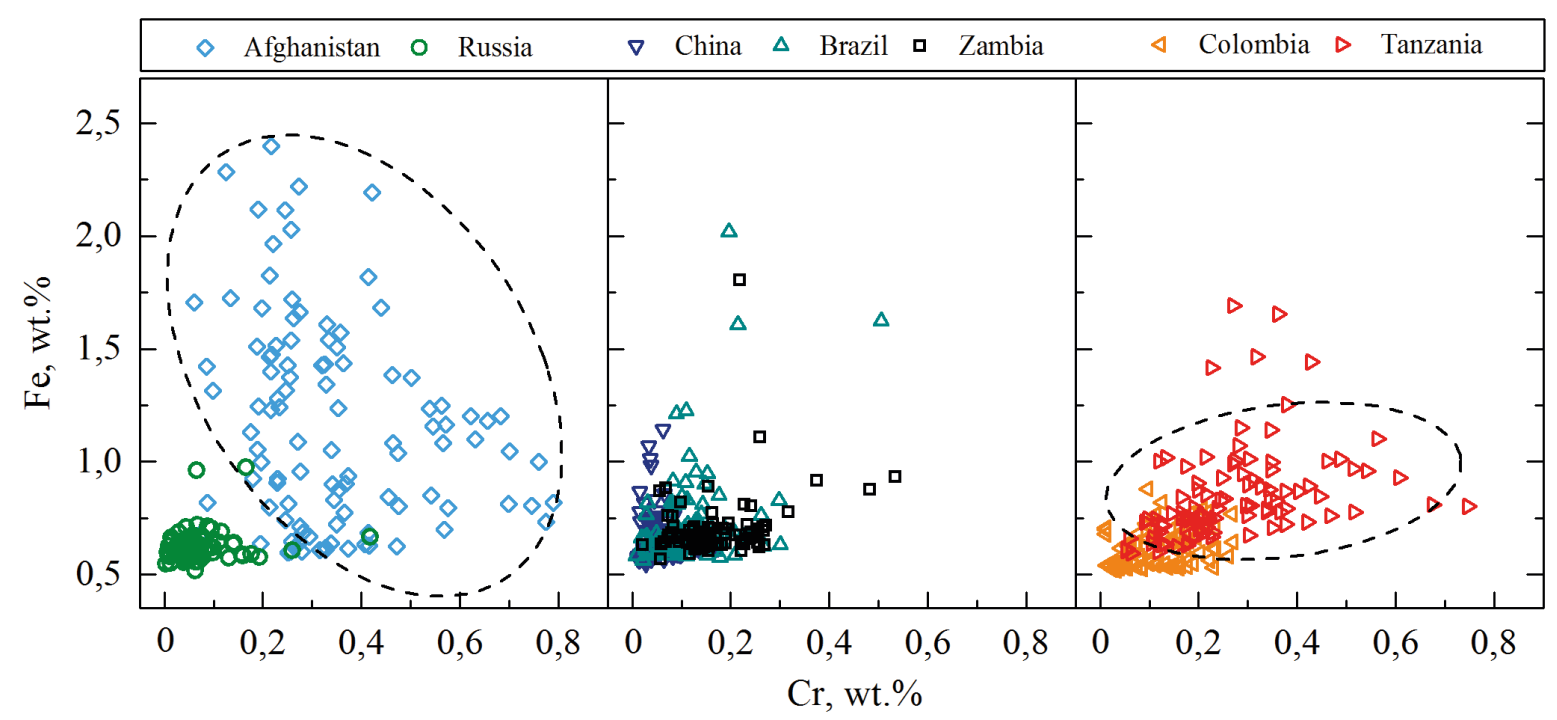

Figure 3. Dependence of the ratio of iron with chromium in emeralds $(\mathrm{Fe}-\mathrm{Cr})$

Рисунок 3. Зависимость соотношения в изумрудах железа с хромом (Fe-Cr) 
several areas inherent to certain deposits are highlighted (by dashed line).

Three regions are distinguished in the $\{\mathrm{Cr}, \mathrm{V}\}$ plane (fig. 1), which belong to samples from Afghanistan, China, and Colombia. A feature of the samples from Afghanistan is an increased content of $\mathrm{Cr}$ and $\mathrm{V}$ impurities, while for the samples from Colombia, with practically the same range of changes in the concentration of vanadium, a reduced content of chromium is observed. In the Chinese samples, an increased V content is observed with low chromium content. Consequently, in these coordinates, the samples from the deposits of Afghanistan, China, and Colombia can be distinguished.

In fig. 2 in the $\{\mathrm{Cs}, \mathrm{Cr}\}$ plane, an increased cesium content is observed in the Chinese and Zambian samples, but the chromium impurity in them are in different ranges. Therefore, the Chinese samples, as well as the samples from Zambia can be distinguished in the separate areas.

As for the samples from Afghanistan and Tanzania, these deposits intersect in two planes $\{\mathrm{Cs}, \mathrm{Cr}\}$ and $\{\mathrm{Fe}, \mathrm{Cr}\}$, but we also identified them, since with the same change in chromium impurity, the ranges of $\mathrm{Cs}$ and $\mathrm{Fe}$ content are still differ.

Conclusion

The data on the impurity composition of emeralds obtained by X-ray fluorescent analysis show that the content of impurities of $\mathrm{Na}, \mathrm{K}, \mathrm{Rb}, \mathrm{Cs}, \mathrm{Mg}, \mathrm{Fe}, \mathrm{V}, \mathrm{Cr}$ differs depending on the deposit. The content of impurities of alkali metals and magnesium is higher in the samples from shale-type deposits compared to the samples from deposits of the Colombian type. Thus, at the first stage, the type of deposit can be assumed. Further, the dependences plotted in the coordinate planes $\{\mathrm{Cr}, \mathrm{V}\},\{\mathrm{Cs}, \mathrm{Cr}\}$, $\{\mathrm{Fe}, \mathrm{Cr}\}$ highlight the separate areas, delimited by the impurity ratios, which are typical for the samples from deposits in China, Colombia, Zambia, Afghanistan, and Tanzania. In addition, the presence of more than 100 samples from each deposit allows a deeper statistical analysis to be applied for further research, including different data processing methods.

Thus, X-ray fluorescent analysis, as a non-destructive method for examing emeralds, is considered to be a promising approach to identifying their deposit, but as an additional method

The work was carried out within the framework of the state budgetary theme AAAA-A18-118052590032-6 "Paleogeodynamics and evolution of structural-material complexes during the formation of the continental type of crust (using the Ural-Mongolian fold belt and the West Siberian platform as an example)" and with the support of the Ministry of Science and higher education of the Russian Federation under agreement no. 075-15-2020-931 within the framework of the development program called "Rational development of the planet's liquid hydrocarbon reserves".

\section{REFERENCES}

1. Banks D. A., Giuliani G., Yardley B. W. D., Cheilletz A. 2000, Emerald mineralization in Colombia: fluid chemistry and the role of brine mixing. Mineralium Deposita, vol. 35, pp. 699-713. https://doi.org/10.1007/s001260050273

2. Kazmi A. H., Lawrence R. D., Anwar J., Snee L. W., Hussain S. 1986, Mingora emerald deposits (Pakistan); suture-associated gem mineralization. Economic Geology, vol. 81, no. 8, pp. 2022-2028. https://doi.org/10.2113/gsecongeo.81.8.2022

3. Nassau K., Jackson K. A. 1970, Trapiche emeralds from Chivor and Muzo, Colombia. The American Mineralogist, vol. 55, no. 3-4, part 1, pp. 416-427.

4. Bowersox G. W., Anwar J. 1989, The Gujar Killi emerald deposit, Northwest Fronteir Province, Pakistan. Gems and Gemology, vol. 25, pp. 16-24.

5. Popov M. P. 2014, Geological and mineralogical features of rare metal mineralization in the Eastern exocontact of the Aduyskiy Massif within the Ural Emerald mine. Ekaterinburg, 136 p. (In Russ.)

6. Giuliani G., Silva L. J. H. D., Couto P. 1990, Origin of emerald deposits of Brazil. Mineralium Deposita, vol. 25, pp. 57-64. https://doi. org/10.1007/BF03326384

7. Laskovenkov A. F., Zhernakov V. I. 1995, An update on the Ural Emerald Mines. Gems and Gemology, vol. 31, no. 2, pp. 106-113. https://doi. org/10.5741/GEMS.31.2.106

8. Seifert A. V., Žáček V., Vrána S., Pecina V., Zachariáš J., Zwaan J. C. 2004, Emerald Mineralization in the Kafubu area, Zambia. Bulletin of Geosciences, vol. 79, pp. 1-40.

9. Vapnik Ye., Sabot B., Moroz I. 2005, Fluid inclusions in lanapera emerald, Southern Madagascar. International Geology Review, vol. 47, pp. 647-662. https://doi.org/10.2747/0020-6814.47.6.647

10. Nikolaev A. G., Fakhardo Beharano E. L., Popov M. P. 2016, Optical spectroscopy and comparative crystallochemical features of emeralds of various industrial-genetic types of deposits. Materials of 22 Scientific student school called "Metallogeny of ancient and modern oceans-2016. From mineralogenesis to deposits". Miass, pp. 237-239. (In Russ.)

11. Nikolaev A. G., Popov M. P., Lyutoev V. P., Khasanova N. M., Isayenko S. I. 2017, Comparative crystal-chemical characteristics of emeralds from various genetic types of deposits (Columbian and Ural provinces). Materials of the Jubilee Congress of the Russian Mineralogical Society "200 years of the RMO". Saint Petersburg, vol. 1, pp. 398-400. (In Russ.)

12. Porotnikov A. V. Popov M. P., Gorbunova N. P. 2013, Application of linear discriminant analysis for automatic determination of the origin of emerald according to X-ray fluorescent analysis. Yearbook-2012. Proceedings of the Zavaritsky Institute of Geology and Geochemistry of the Ural Branch of the Russian Academy of Sciences, issue 160, pp. 353-355. (In Russ.)

13. Solomonov V. I., Spirina A. V., Popov M. P. Kaigorodova O. A. 2016, Luminescence properties of precious beryl deposits. Opticheskiy zhurnal [Journal of Optical Technology], vol. 83, issue 8, pp. 494-497. (In Russ.) https://doi.org/10.1364/JOT.83.000494

14. Solomonov V. I., Spirina A. V., Popov M. P., Ivanov M. A., Lipchak A. I. 2019, Statistical luminescence method for determining the region of origin of emeralds. Opticheskiy zhurnal [Journal of Optical Technology], no. 86, issue 7, pp. 447-451. (In Russ.) https://doi.org/10.1364/ JOT.86.000446

15. Popov M. P., Gorbunova N. P. 2018, Features of studying the composition of emerald using the spectrometer EDX-8000, Yearbook-2018. Proceedings of the Zavaritsky Institute of Geology and Geochemistry of the Ural Branch of the Russian Academy of Sciences, issue 166, pp. 238-241. (In Russ.) 


\title{
Анализ геохимических особенностей кристамизации изумрудов как способ определения их месторождения
}

\author{
Михаил Петрович ПОПОВ ${ }^{1,2 *}$ \\ Владимир Иванович СОЛОМОНОВ $3,4 * *$ \\ Альфия Виликовна СПИРИНА ${ }^{3 * * *}$ \\ Михаил Алексеевич ИВАНОВ 5 , \\ Виктория Владимировна КУПЦОВА 5 , \\ Анатолий Германович НИКОЛАЕВ ${ }^{6 * * *}$
}

1Уральский государственный горный университет, Екатеринбург, Россия

${ }^{2}$ Институт геологии и геохимии им. акад. А. Н. Заварицкого УрО РАН, Екатеринбург, Россия

зинститут электросризики УрО РАН, Екатеринбург, Россия

4Уральский федеральный университет им. первого Президента России Б. Н. Ельцина, Екатеринбург, Россия

${ }^{5}$ Войсковая часть 68240, Москва, Россия

${ }^{6}$ Казанский (Приволжский) федеральный университет, Казань, Россия

\section{Аннотация}

Актуальность. Известно, что минералы различаются по морфологии, особенностям внутреннего строения кристаллов, химическому составу и др. в зависимости от условий их образования и существования. Эти геохимические особенности кристаллизации самоцветов являются важным критерием для определения их месторождения. В данной работе исследовался примесный состав выборки изумрудов из месторождений Бразилии, Китая, Замбии, России, Афганистана, Колумбии и Танзании методом рентгенофлюоресцентного анализа (РФА). Исследование примесного состава изумрудов и построение аналитических зависимостей с использованием неразрушающего метода может быть использовано в качестве дополнительного способа определения месторождения изумрудов.

Цель работы - исследование химического состава изумрудов методом рентгенофлюоресцентного анализа для установления взаимосвязи между содержанием основных примесных элементов и регионом происхождения.

Pезультаты. Данные по примесному составу изумрудов, полученные с помощью рентгенофлюоресцентного анализа, показывают, что содержаниепримесей $\mathrm{Na}, \mathrm{K}, \mathrm{Rb}, \mathrm{Cs}, \mathrm{Mg}, \mathrm{Fe}, \mathrm{V}, \mathrm{Cr}$ из разных месторождений отличается. Содержание примесей щелочных металлов и магния выше в образцах из сланцевых месторождений по сравнению с образцами из месторождений колумбийского типа. Это позволяет на первом этапе делать предположение о типе месторождения. Построенные в координатных плоскостях $\{\mathrm{Cr}, \mathrm{V}\},\{\mathrm{Cs}, \mathrm{Cr}\},\{\mathrm{Fe}, \mathrm{Cr}\}$ зависимости демонстрируют отдельные области по соотношениям примесей, которые характерны для образцов из месторождений Китая, Колумбии, Замбии, Афганистана и Танзании.

Вывод. Рентгенофлюоресцентный анализ как неразрушающий метод исследования изумрудов рассматривается перспективным подходом к идентификации их месторождения, но в качестве дополнительного метода.

Ключевые слова: изумруд, месторождение, примесный состав, рентгенофлюоресцентный анализ.

ЛИТЕРАТУРА

1. Banks D. A., Giuliani G., Yardley B. W. D., Cheilletz A. Emerald mineralization in Colombia: fluid chemistry and the role of brine mixing // Mineralium Deposita. 2000. Vol. 35. P. 699-713. https://doi.org/10.1007/s001260050273

2. Kazmi A. H., Lawrence R. D., Anwar J., Snee L. W., Hussain S. Mingora emerald deposits (Pakistan); suture-associated gem mineralization // Economic Geology. 1986. Vol. 81. No. 8. P. 2022-2028. https://doi.org/10.2113/gsecongeo.81.8.2022

3. Nassau K., Jackson K. A. Trapiche emeralds from Chivor and Muzo, Colombia // The American Mineralogist. 1970. Vol. 55. No. 3-4, part 1. P. 416-427.

4. Bowersox G. W., Anwar J. The Gujar Killi emerald deposit, Northwest Fronteir Province, Pakistan // Gems and Gemology. 1989. Vol. 25.

P. 16-24.

5. Попов М. П. Геолого-минералогические особенности редкометалльной минерализации в Восточном экзоконтакте Адуйского массива в пределах Уральской изумрудоносной полосы. Екатеринбург: УГГУ, 2014. 136 с.

6. Giuliani G., Silva L. J. H. D., Couto P. Origin of emerald deposits of Brazil // Mineralium Deposita. 1990. Vol. 25. P. 57-64. https://doi.org/10.1007/ BF03326384

\footnotetext{
$\triangle$ popovm1@yandex.ru

http://orcid.org/0000-0002-0527-8234

*plasma@iep.uran.ru

**asuleva@iep.uran.ru

****anatolij-nikolaev@yandex.ru
}

20 M. P. Popov et al. An analysis of geochemical features of crystallization of emeralds as an approach to determine the deposit of them// Известия УГГУ. 2021. Вып. 2 (62). C. 16-21. DOI 10.21440/2307-2091-2021-2-16-21 
7. Laskovenkov A. F., Zhernakov V. I. An update on the Ural Emerald Mines // Gems and Gemology. 1995. Vol. 31. No. 2. P. 106-113. https://doi. org/10.5741/GEMS.31.2.106

8. Seifert A. V., Žáček V., Vrána S., Pecina V., Zachariáš J., Zwaan J. C. Emerald Mineralization in the Kafubu area, Zambia // Bulletin of Geosciences. 2004. Vol. 79. P. 1-40.

9. Vapnik Ye., Sabot B., Moroz I. Fluid inclusions in lanapera emerald, Southern Madagascar // International Geology Review. 2005. Vol. 47. P. 647-662. https://doi.org/10.2747/0020-6814.47.6.647

10. Николаев А. Г., Фахардо Бехарано Э. Л., Попов М. П. Оптическая спектроскопия и сравнительные кристаллохимические особенности изумрудов различных промышленно-генетических типов месторождений // Металлогения древних и современных океанов-2016. От минералогенеза к месторождениям: материалы 22 науч. студенч. школы. Миасс: Ин-т минералогии УрО РАН, 2016. С. 237-239.

11. Николаев А. Г., Попов М. П., Лютоев В. П., Хасанова Н. М., Исаенко С. И. Сравнительная кристаллохимическая характеристика изумрудов из различных генетических типов месторождений (Колумбийская и Уральская провинции) // 200 лет РМО: материалы юбил. съезда Российск. минералог. общ-ва. СПб, 2017. Т. 1. С. 398-400.

12. Поротников А. В., Попов М. П., Горбунова Н. П. Пр именение линейного дискриминантного анализа для автоматического определения происхождения изумруда по данным рентгенофлюоресцентного анализа // Ежегодник-2012: труды ИГГ УрО РАН. 2013. Вып. 160. С. 353-355.

13. Соломонов В. И., Спирина А. В., Попов М. П., Кайгородова О. А. Люминесцентные признаки месторождений драгоценных бериллов // Оптический журнал. 2016. Т. 83. № 8. С. 58-62. https://doi.org/10.1364/JOT.83.000494

14. Соломонов В. И., Спирина А. В., Попов М. П., Иванов М. А., Липчак А. И. Статистический люминесцентный метод определения региона происхождения изумрудов // Оптический журнал. 2019. № 86. Вып. 7. С. 447-451. https://doi.org/10.1364/JOT.86.000446

15. Попов М. П., Горбунова Н. П. Особенности изучения состава изумруда на спектрометре EDX-8000 // Ежегодник-2018: труды ИГГ УрО РАН. 2018. Вып. 166. С. 238-241. 